\title{
Coming back home: the reconstruction of the identities of the homecomers ${ }^{1}$
}

\begin{abstract}
This article discusses the comings and goings of Brazilian migrants in the early 21st century. Returning is a constituent stage of the migration project. Many men and women, when setting out to America, claimed their intent to come back when completing their migration project, which is usually translated as acquiring enough resources to purchase a house, a vehicle, and to start a business. This article discusses how men and women go through the experience of returning to the homeland to analyze how they reconstruct the path home and which effects of travel appear in the identity configurations, as well as in familial and gender relations. "It's easier to leave than to come back," migrants say. Thus we intend to demonstrate that returning is more complex, and that, in several cases, migrants live between two places, forming a transnational identity.
\end{abstract}

Keywords: Transnationalism. Return. Memory.

\author{
Glaucia de Oliveira Assis \\ Ph.D. in Social Sciences from the \\ Campinas State University (UNICAMP). \\ Professor at the Department of History and the \\ Graduate Program in History of the Santa \\ Catarina State University (UDESC). \\ Florianópolis - SC - BRAZIL \\ galssis@gmail.com \\ orcid.org/0000-0002-0307-6313

\section{Emerson César de Campos} \\ Ph.D. in History from the Federal University of \\ Santa Catarina (UFSC). Professor at the \\ Department of History and the Graduate \\ Program in History of the Santa Catarina State \\ University (UDESC). \\ Florianópolis - SC - BRAZIL \\ ecdcampos@yahoo.com.br \\ orcid.org/0000-0002-1455-4528
}

DOI: $10.5965 / 2175180311282019553$

http://dx.doi.org/10.5965/2175180311282019553

\footnotetext{
${ }^{1}$ Data for this article derives from the research project "Flowing from Local to Global: Social social networks built between Santa Catarina and Boston (USA) in the early 21st century", financed by FAPESC, as well as the project "Foreigners at home: feelings, impressions, and (re)identifications produced by clandestine Brazilian immigrants in the United States after returning to Santa Catarina (1995-2005)".

* Translation of the article "DE VOLTA PARA CASA: a reconstrução de identidades de emigrantes retornados" published in the Journal Tempo e Argumento, Florianópolis, v. 1, n. 2, p. 80-100, jul./dez. 2009.

** Translated and revised by Meggie Fornazari and Filipe dos Santos Avila

*** The translation of this article was funded with resources from the project Brasil em notícias: narrativas sobre famílias e infâncias (1964-1990). Chamada Pública FAPESC Nº1/2016. (APOIO À INFRAESTRUTURA PARA GRUPOS DE PESQUISA DA UDESC).
} 


\begin{abstract}
Resumo
Este artigo pretende discutir $\mathrm{o}$ ir e vir de emigrantes brasileiros neste início de século XXI. O projeto de retorno é parte constitutiva do projeto migratório. Muitos homens e mulheres, quando partiam para "fazer a América", afirmavam que pretendiam voltar para o Brasil quando conseguissem realizar o projeto migratório, em geral traduzido como reunir os recursos suficientes para comprar uma casa e um carro e montar um negócio. O artigo pretende discutir como homens e mulheres vivenciam a experiência de retornar à terra natal, procurando analisar como reconstroem o caminho de volta para casa, quais os efeitos das viagens nas configurações identitárias, nas relações familiares e de gênero. "Voltar é mais difícil do que partir", dizem os emigrantes. Assim, pretendemos demonstrar que 0 retorno é mais complexo e que, em muitos casos, os emigrantes passam a viver entre dois lugares, configurando uma identidade transnacional
\end{abstract}

Palavras-chave: Transnacionalismo. Retorno. Memória.

\title{
Introduction
}

The city of Criciúma, located in southern Santa Catarina state, had a new populational move in the late 2oth century similar to other Brazilian cities such as Governador Valadares (MG) and Maringá (PR): they migrated to the United States and Europe. The first immigrants from Criciúma left for the United States in the mid-1960s, but the flow became significant in the early 1990s, both for those who left and for those who stayed. Thus, they sewed a field of transnational relations that began to be observed in the city's everyday life.

When they left, migrants from Criciúma carried their desire for a better life in their migratory projects. Several of them carried Italian passports, as they descended from immigrants who, in turn, came to the region in the late 19th century. Others dived in, traveling with Tourist visas or risking their lives in the Mexican border, as several reports 
in this text will show. In both cases, they shared a migration project: working and saving enough to buy a home, a car, and to start a business in Brazil - these assets would mean their project was successful. Thus, their migration project was constructed as temporary, and returning to Brazil was a part of it.

Migrants, when leaving for a better life abroad, intend to return, at some point, to their homeland. This desire was revealed in their letters or when questioned and is translated in their self-definition as temporary migrants. Several migrants mentioned plans to return to Brazil. Usually, their return is scheduled for the end of the year, as the Holidays are a moment to see family. For many migrants, that time of the year is the most difficult time to stay in the United States.

Between the "desire to go home to Brazil" and what happens in effect lies a gap. Some only take holidays, others cannot, as many people lack the courage to return without acquiring something. And time passes.

This article seeks to follow the trajectory of migrants on their way home. We will discuss their return experiences from semi-structured interviews and oral reports. This ethnographic study was performed with migrants returning to the city of Criciúma, and with people who intended to return or had re-migrated to the Boston area. We also intend to present data available on migration from Criciúma, as it allows us to shape a profile on absent migrants, as well as returned and transmigrants. Fifteen interviews were conducted and transcribed with returning migrants ${ }^{2}$, men and women between the ages of 23 and 53 from various social segments. Interviewees had a minimum of two years experience in the United States, without legal documents, and have returned to Criciúma for at least one year at the moment of their interviews. To obtain broad and consistent results, it seemed appropriate to articulate information with some field work in the United States. Thus, between June 19 and July 8, 2008, we interviewed 22 Brazilians in the states of Massachusetts and New York, staying there legally or not.

"It's easier to leave than to come back" is a recurring phrase among migrants. With that, we intend to demonstrate that the return is complex and that categories such

\footnotetext{
2 All interviews are properly transcribed and stored digitally.
} 
To better understand the return project, it's important to analyze the migration path. To do so, a brief history of the configuration of migratory networks will be presented to analyze the return movement, which has intensified since 2007. It's also important to point out that since this is a recent movement, returning, leaving, and staying are mixed within these migrants' lives. This configures a circularity of people and projects that have modified the city dynamics, impacting not only economic life but the identities of the subjects going through this process.

\section{The first Criciúma-United States connection: migrants in the 1960 s}

After World War II, a new agricultural and livestock production model was implemented in Brazil, commanded by the capital and with strong North-American influence, aimed at overcoming "backwardness" in agriculture. To "educate" farmers to use new production techniques and increase production, the state of Santa Catarina implemented a project named Clubes 4-S. These clubs peaked in the 1970 s and were dedicated to educating young farmers while fostering exchange trips with American farmers. Brazilians could learn new techniques in the United States, and young Americans who came to live in Brazil could pass on their techniques to their hosts.

In southern Santa Catarina, Clube 4-S brought Americans and their culture closer to Criciúma, creating bonds between these peoples and serving as a panel to spread American modernity. This can be observed in the newspaper Tribuna Criciumense in the issue of August 21-28, 1965, featuring the story of Bob Harter, a parting American that claimed he would never forget Criciúma and its people. That newspaper also featured, in the issue of September 11-18th, 1965, the story of Ilma Arna, a woman from Criciúma who went to the United States to study agricultural techniques. Besides these trips promoted by the $4-S$, there were study exchange programs promoted by the Rotary Club, which were common after 1960 (SANTOS, 2007). 
spread into the masses soon after the end of World War II, in an American attempt to include Brazil in its roster of economic and military partners. At that time, we saw products made in the United States arriving in Brazil, such as Sesame Street (an originally American TV show), the Susi doll (a copy of Barbie), Disney comics, and American cinema (the first movie theater in Criciúma was opened in 1950).

In 1965, Tribuna Criciumense had a weekly column entitled "Facts," presenting information on the United States such as new wall paints or how to wear a 'cowboy' hat (SANTOS, 2007). According to a study by Santos (2007), in 1965 about $80 \%$ of the international news and advertisements in that newspaper were dedicated to the United States.

There is then an increase in travels to the United States, but not everyone had the financial means to make such airplane trips. However, a new elite of coal and ceramics emerged at that time, as well as an urban middle class that could afford to buy modern goods and traveling as tourists to the United States. This wealthy lifestyle was diffused by the media to other social classes. As an example of how this imaginary about the United States was formed in the city, the Independence Day parade, on 7 September 1976, had a boy dressed as Mickey Mouse (CAMPOS, 2003).

Often, such an image is enough on its own to stimulate a desire to migrate. In an interview, Aldir³, born in Criciúma in 1966 and migrated to the United States in 1992, made clear how the imaginary about life in America was constructed.

Gláucia: What you just mentioned about going to the United States, when you say that it's not just about the money, what you said about putting a man on the moon, of the movies...

Aldir: Of course, it's an illusion, but it's never not real; humans live on a bit of illusion, ain't it so? Of dreaming... It's not so...

\footnotetext{
3 Since these migrations were largely undocumented migration, the names in this study report are fictitious. The exception are people publicly identified in the city and in local media as migrants. Interview given by Aldir Losso in June 2008 in the city of Lowell, Massachussets.
} 
Gláucia: I'm trying to think of what you're talking about, what do you mean it's not just about the money? What was the dream?

Aldir: Of course, about that boyish dream, of those movies I saw, like - oh my, everything's so wonderful out there, I want to see it up close! I can't be like this, living a whole life without seeing it! To me it didn't make sense; it didn't make sense. So, that's it...

Gláucia: You came after your dream?

Aldir: I came after my dream, you might say so. When I was a boy I always said, I always had that...

Gláucia: You always had that desire.

Aldir: I always wanted to.

Gláucia: You never wanted to go to Italy, Portugal?

Aldir: No, l'd always say: I'm going to the United States, one day l'll stop by Canada, because it's nearby - right next to it, in my boy's head, nearly the same culture.

Aldir, in his testimony, reminisced about when the Carminatis returned to Criciúma after their first migratory experience in the United States. Their image of successful migrants that they conveyed and the information that began to circulate through them about, for example, nightclubs.

Jaci Carminati is considered by some as the pioneer in the migration of people from Criciúma to the United States. Jaci studied at a seminary in Minas Gerais, and there he befriended a young man who later migrated to the United States. He migrated to the United States in 1966 himself, with his friend aiding him to find work. After settling in the country, Jaci found employment for his brother, Dino Carminati, who went there in 1969.

Dino reported on his migratory experience in an interview granted in June 2008. According to Dino, at the time it was very easy to get a green card and become legal in the country - it sufficed to prove you had a job in the United States to get the visa. Dino reports that by the time he arrived in the United States he already knew of five Brazilians living in the city of Manchester alone, around Boston, and Jaci had brought one of them. He also provided details of a trip he and his brother took by car from the United States to Criciúma in 1970. That trip was reported on local radio, and they were received with great celebration as soon as they arrived in town. Dino returned to the United States in 1971, bringing their third brother. 
Dino Carminati: My brother had [A Mustang], and Jaci said, "Dino, let's go to Brazil by car, come on." I'd say, "No, you're crazy; it's too far!” But then he nagged and nagged, and after a month I said, "Oh so you wanna go? Alright then.

(...)

Dino Carminati: Then we went to the main office and said, "Listen, we want to go to Brazil. Can you help us?" They got our licenses, photographed the international ID for us to travel, and gave us a map with the route and everything, and we got insurance if we had any problem, right? There was a risk in our lives. So we got the insurance and left on December 5, 1970.

The Mustang trip from America to Criciúma was narrated as an adventure, with a mix of pride and longing. Dino says they drove to Panama. From there, as no more roads were available, they ferried off the car and flew to Lima, in Peru. They spent a week in Peru, waiting for the car and getting to know the city and their historical sites:

Dino: Oh, we saw everything there was to see in Lima. We took a bus in the morning, left and came back at night. We saw everything, you know, those Inca places? Those things that they have there. We got there in the morning, very early, asked around, "where do you have a tourist spot?" "Oh, there's a place, such and such." We took the bus here and left in the morning to get back at night.

Getting to know Latin America, or some of it, was a part of the trip, even if unplanned. Dino recounts the places he went through and doubts on which way to go. They passed through Lima and saw "those Inca places," passed by Venezuela and went straight to Chile. When narrating their trip, the highlight was the journey itself, the crossing of borders, and the arrival in Criciúma. After sixteen days and six hours of traveling, as reported by Dino and followed by local radio news.

Dino had returned to Brazil to get engaged and married. However, he came back without his wife, who waited for his brother's wife to travel together. The first women of Criciúma migrated following their trajectory: Neide and Mirces left to meet their husbands after marrying in Brazil. They traveled together at the age of 24 in the early 1970s. Mirces ${ }^{4}$ retells her departure:

\footnotetext{
4 Mirces Jucelia Moreira, interview given in December 2008, in the city of Criciúma to Emerson César de Campos, Gláucia de Oliveira Assis, and Sueli Siqueira.
} 
Jaci really went up before everyone else. So when I learned to speak Spanish with these two friends... They even wondered why to Americans Brazil was Latin America. So they thought I was dark-skinned and even, so they said, "fine, but you look American! You have long, blonde hair..." And Neide, Jaci's wife, was a green-eyed blonde... And a bunch of women from here was, too. So they thought it was strange that the city we were in had no Brazilians, and very few foreigners, only Dino, Arnaldo, Valdir, and $[\ldots]$.

Throughout her account, Mirces always marks the distinction between Brazilians and other Latinos, and among Brazilians as well; as southerners, they had another ethnic identity that made them seem different from other Brazilians. Looking like NorthAmericans in some contexts was an advantage to these Italian descendants who migrated to "make it in America." It is also important to point out that, similarly to other immigrants of that time, Mirces was already employed as a teacher. She had her profession but chose to migrate to follow Dino. She thus reports her motivation to go to her family's reaction:

Gláucia: When did you tell your parents that you were going? What was it like?

Mirces: My mom was a little apprehensive, and so was I. Because I didn't know... It's a whole new world, right?

Sueli: But why did you choose to go?

Mirces: I don't know. Because Dino thought of going, his brothers were there already, and we were young, we really went on adventures. I was tired of teaching, so I did the math: I spent this much here, this much there, ends didn't always meet, I had to... You know?

Mirces and Neide began their migratory experience by following their husbands, unlike reports found in Governador Valadares (Minas Gerais). In their first waves of migrants figured some single women (ASSIS AND SIQUEIRA, 2008). However, it is interesting that Mirces highlights in her accounts are her wish for adventure. They were all young people in search of adventures.

Neide and Mirces remained in the United States until the early 1980s, when they returned to Brazil with their husbands and children. According to a report by Dino Carminati, his wife Mirces worked in a factory and had two children, but she could not stay in the United States any longer because she missed her family in Brazil. Mirces was naturalized to facilitate the migration of her relatives. However, only one brother 
in the city of Criciúma and the nearby Rincão beach. They owned the nightlife in the city during that decade, as well as businesses that showed the success of their return trajectories. While the brothers set up nightclubs, Mirces opened an English school in Criciúma and returned only temporarily to the United States. Neide, Jaci Carminati's wife, opened a store in Criciúma to sell clothing purchased in the United States.

Mirces, as a migrant, returned twice before returning definitively to the city of Criciúma in 1983. As we will see, returning is not always as expected, and re-migration became a part of her family trajectory. She thus describes her reason to return to Brazil for the first time:

Mirces: Look, she [daughter] was three years old, and my son was 8.1 didn't want them to... We didn't mean to spend the rest of our lives there; we didn't. I always wanted to come home. So it was time to do it. 'Cause he was 8 , he was in elementary school there and here he went through a lot at São Bent because there were no teachers to, you know... Ah, it was stressful. l'd teach him extra classes at home, and he'd go to school in the afternoon... Look, he was even stressed. Even on vacation, the Sister said, "look, let this boy play a lot because it was really difficult for him to adapt here." So I think that if you have children and you want to go back, wait until they're teenagers or there's no helping them! How are you going to do it? What about school? What about college? So we thought it was time to come home, and I do not regret having come. Not even a little bit.

In a recent interview granted to the researchers, Mirces Carminati says to have completed her stage in the migratory current. She tried to return to the United States about three years ago, with her daughter (and husband Dino, who was already there). She stayed there for eight months and then decided to return to Brazil indefinitely5. When commenting on her re-migration to the United States, she synthesizes her attempt to live there again:

\footnotetext{
5 Mirces also said at the time that she had been trying to recover social rights in the United States, such as social security and equivalents to retirement in Brazil. Her husband Dino still lives and works in Lowell, Massachussets, waiting for his retirement to be granted in 2009.
} 
Mirces: "No, because I went to stay there with Dino for a bit, really. Since he was... And I wanted a break from the [English] school, too. It was already time to..., right? Then "oh, so I'll go there, spend some time there," and she [the daughter] also wanted to improve her English, so I said, "so let's go. But you can't. What we have... [Inaudible] What we have in applications, oh God! I've had it! And then we couldn't get a job anywhere. You see? Anywhere. Even in places, like... Even in Boston? A place with a bunch of Brazilians, all illegal, that we knew they were."

Mirces, although documented and able to speak English, could not enter the US job market in 2004 and returned to Brazil, where she lives with her daughter. The family lives between two places because of documentation - the daughter has North-American citizenship as she was born in the USA, and that gave citizenship to the mother as well. Thus, they can move between the United States and Brazil. However, it seems that mother and daughter cannot readapt to the life of a Brazilian immigrant in a small town full of foreign workers, including several Brazilians, and preferred to return to Brazil.

The trajectory of the Carminati brothers is always told in the city as a migratory success, and several interviewed migrants referred to them as sources of information, or helpers, to some extent, for people who migrated after them.

Jaci Carminati maintained a column in the city newspaper throughout the $1990 \mathrm{~s}$ and a small business in Boston that specialized in guiding migrants to get driver's licenses, paying taxes to the US government, and sending money to Brazil. Also, he organized a few parties in the city of Sommerville. Some of them contributed to raising money for the film "A Fronteira" (2001), that told the experience of Brazilian migrants and was produced by US-born Roberto Carminati, his son.

The experience of the Carminati family demonstrates how middle-class families from a medium-sized city sought social mobility, or opportunities, as they say, in the United States in the turn of the 1960 s to the 1970s. These first migrants, upon returning to their hometowns, with their accounts and investments, became references to the possibility of the "American Dream." In a sense, they have achieved what was expected from migration: to purchase a house and a car, as well as setting up a business. We can say that this family has lived between the two places since the mid-1980s. When returning to Criciúma for the first time, their experience was followed by newspapers. The visibility 
In this sense, the first migrants' reporting of their experiences upon returning and demonstrating their "migratory success" in their hometowns contributed to constructing an image about the USA. They aided in forming connections with the Boston region, as they supplied information, contacts, and welcome for those who followed them.

\section{Coming and Going - The Impact of Migration on the City's Everyday Life: migrants in the $2000 \mathrm{~s}$}

Throughout the last two decades of the 2oth century, Brazilians living abroad built multiple economic, cultural, and family relations. This suggests that migrants, even if absent while abroad, continue in touch with their hometowns (ASSIS, 1995; SALES, 1999). Such contact is translated into investments in their hometowns, driving local markets (notably civil construction, and thus driving the real estate market), which also fosters small business financed by the dollars received by their relatives. Such investments changed the lives of cities that became starting points for migration, such as Governador Valadares $^{6}(\mathrm{MG})$, Criciúma (SC), ${ }^{7}$ and Maringá $(P R)^{8}$. Throughout the last few decades, these cities have constructed a myriad of relations between their hometown and their city of migration. Investments show that migrants have plans to return to the country and stay in touch with it. Added to the deposits made to support family members who remained in the country, investments accounted for US\$ 2.6 billion dollars entering the country in $2002^{9}$.

\footnotetext{
6 On the real estate dynamics in Governador Valadares, see Soares (1999).

7 According to Manoel Alves, president of the Criciúma real estate administration union (Sindicato de Compra, Venda e Administração de Imóveis de Criciúma), real estate business grew in 30\% between December and January, when migrants go visit their relatives or return to Brazil (Vitali, Marli. Moradores da região sul tentam a sorte nos Estados Unidos. Jornal A Noticia. Caderno AN Economia, p. B2, 16/01/2000). On another news story, president of Criciúma United Soccer Club Gilson Marcos claims that approximately US\$ 800,000 would reach the city through tourism agencies, banks, and exchange (Mendes, Maneca. Criciumenses em Boston - Chegam US\$ 800 mil por mês dos Estados Unidos. Jornal da Manhã, 15 e 16 de abril de 2000).

8 On the Dekassegui shipments, see SASAKI (1999).

9 Folha de São Paulo, 18/08/2002.
} 

amount of the urban population of (riciúma).

In Assis' 2004 study, international migrants were those individuals who had had some experience of living abroad for more than three months - either to work, study, or follow family members. The group was divided between "absent abroad" and "returning." The absent were abroad at the time of the study and made up for $25.2 \%$ of people in households with migratory experience. Returnees were those who had some experience of international migration for over three months and were in Brazil at the time of the study, which constituted $9 \%$ of the studied group. Such data show that $34.2 \%$ of individuals in the $4.3 \%$ of Criciúma households were going through or had gone through the experience of migrating abroad. The data also indicates that there were more migrants absent abroad than returning, which indicates that when the study was performed (2001), the migratory move was expanding. Data collection was performed before the attacks in 9/11 and the economic crisis that hit the United States in mid-2007 and became more severe in 2008. After these events, we observed a greater wish to return in the reports of migrants, as well as a major increase of returnees. ${ }^{10}$

On the July 10th, 2003 issue of Jornal da Manhã, we found a news piece telling the story of Renato Inacio, who lived and worked in the United States and opened his own business upon returning. Today he owns a pizzeria and is one of the first to implement the all-you-can-eat pizza buffet, as well as working with the Greek dough, which, in his opinion, is softer than the Italian. Ronaldo and Renato Inácio are migrants with green cards and, for that reason, continued coming and going to the United States while keeping their business and family in Brazil. This coming and going sets up a field of transnational relations. In July 2008, during our fieldwork in Boston, we saw Renato Inacio, who had returned to the United States to work. He succeeded in doing so due to his documents, which allow him to cross borders without the fears and risks of undocumented migrants.

\footnotetext{
${ }^{10}$ On a second moment of this research, we intend to retake the survey in the city to identify the impact of this return of Criciúma migrants.
} 
The story of Renato (and his brother Ronaldo) is similar to that of other migrants who, after setting up their business in Brazil, had to return to the United States - either to collect capital or because their businesses broke. Returning in this context may prove to be frustrating. Recurring reports show businesses opening and closing with migration dollars, often because the accumulated capital to build a business was not enough to keep it open. This has led to constant re-migrations, intensifying the connection between Criciúma and the Boston area. As the United States economic crisis became more severe, this had a direct impact on the city's commerce and civil construction, as seen in the reports below. Criciúma (as well as Governador Valadares) does not count with a migrant association that tries to act in the destination or with local commerce associations or SEBRAE in setting up courses to train the returned in how to invest their resources, which makes stories like these seem recurrent. ${ }^{11}$ There is a home for state migrants (Casa do Migrante (atarinense), which does not have enough support and resources to help migrants abroad effectively.

Another impact of migration in the city is the investment in civil construction. On the newspaper Gazeta Mercantil (August 2, 2001) we found a small article recording that $20 \%$ of all Construtora Fontana's revenues came from migrants.

Some real estate agents in Criciúma opened branches in the Boston area, in the city of Somerville, to sell homes in Brazil for the migrants. Bia Tramontim, the owner of a real estate agency in Somerville, reported that migrants look at the blueprints, but relatives who stayed in Brazil follow the construction, sending them pictures and footage. Thus, many migrants return to Brazil into a ready home.

In July 2008, on another fieldwork integrated with this project, 37-year-old Alan Cardoso who arrived in the United States through Mexico in 1994 reported that:

(...) Today [2008] I can say I'm financially accomplished, pioneering in establishing a Brazilian real estate agency here in the region. Even with the crisis, the business continues to move proper capital. You can check out our real estate releases up to Florianópolis, where people have been investing more and more. ${ }^{12}$

\footnotetext{
${ }^{11}$ For an analysis of returned migrants in Governador Valadares and their trajectories, see the work of Sueli Siqueira (2006).

${ }^{12}$ Interview given to researchers by Alan Cardoso (fictional name) in the city of Everett (United States) on July 2nd, 2008.
} 
Although data on investments in Criciúma are estimates and could be overestimated, information emphasizes the importance of remittances to the homeland. They also reveal a network of tourism and real estate agencies that are part of this migratory move. At this point, relative networks intertwine with tourism and real estate agencies in the migratory project, doing a very lucrative business. A woman who worked with her husband in the cleaning business in Boston and built her dream home upon returning showed her Criciúma home and said: "If only our bosses could see what we made out of each 50 dollars..."

Alongside the column written by Jaci Carminati in the Jornal da Manhã issue of July 11th, 2003, an advertisement of Imobiliária Bem Morar read the following: “A Brazilian real estate in the Boston area." Followed by an address in the town of Somerville and another message: "Remember: 'To invest in real estate is to think about the future." Estimates from the Diocese of Criciúma reveal the entry of US\$ 533 million in the region, and two-thirds of the income generated by migrants was applied to their homeland (ZAMBERLAM, 2007).

Some insightful data were observed by Assis (2004) regarding remittances, or how migrants sent money from the United States to Criciúma: $40 \%$ of them sent the money for their wives to manage or invested the money on assets in town. The data also reveal that heads of households and their spouses are those with the biggest obligations with those who remained in Brazil, so they send more remittances to those relatives. In this sense, remittances are an important indicator of achievement in a migratory project. According to the statements of the migrants and their relatives who remained in Criciúma, sending remittances represents not only a material return to the migration project but also the maintenance of symbolic ties with those abroad. Their sending of remittances demonstrates that they care about those who stayed behind. Heads of households and their spouses acted under that rationale, and when they didn't do it, it meant they were "abandoning the family," as migrants say (ASSIS, 2004).

Migrants from Criciúma, similarly to other international migrants, leave with an initial project of working and saving money to improve their standard of living in their country of origin. This is why returning is part of the migration project and is present in 
their accounts. This state of provisionality that tends to perpetuate itself, as observed by Abdalmalek Sayad, defines the temporal expectations of migrants. In the early 2000s, many migrants no longer thought of returning to Brazil, having structured their lives in the United States. However, a conjuncture of several factors (the attack on September 11th that caused stronger border control and visa issuance, as well as persecution of illegal workers; the severity of the economic crisis that contaminated the American real estate market since 2007 and stretched into world economy) made migrants rethink their provisional permanence. Many were forced to return because of the difficulty in continuing to find undocumented work, for losing their homes in the financial crisis that also affected immigrants, or by the significant increase in deportations of Brazilians. Upon returning, they did not recognize themselves in their own home or, as Homi Bhabha says, felt foreign at home.

Some testimonials are emblematic in this sense. Fernanda Consoni spent ten years in the United States with her husband and two children and is back in Criciúma for a year and a half. She says she feels a lot of difference between the city she left and the one she found upon her return. Although she continues to claim she feels like a foreigner at home, she says it was important for her to have a support network both there and in Brazil. Also a member of a Protestant church, she decides that "Consumption is a blessing" (CONSONI, 2007). ${ }^{13}$

If in the early 2000 s the flow from Criciúma to the United States could be understood as an expanding move (SANTOS, 2007), it decreased throughout the first decade of the 21st century, with a large number of returns. In the interview above with Dino Carminati, he mentioned a travel agency near Boston that, according to him, sold 27,000 one-way tickets to Brazil in 2007 alone. Among the reasons given by the interviewee for this mass return, we could identify the greater American surveillance of illegal immigrants, the drop on dollar exchange, the increase of unemployment in the United States, and the crisis of the American economy. When asked about what advice he would give to a Brazilian considering moving to the United States, he "does not recommend that any Brazilian goes there."

\footnotetext{
${ }^{13}$ Interview granted to the researchers by Fernanda Consoni (fictitious name) on August 23rd 2007 in Criciúma.
} 
As seen, Criciúma constructed several bonds between the city and the region of Boston. It is from that perspective that we can understand how this southern city became a new starting point for Brazilian migrants. It's possible to observe that some Brazilian cities (following the example of Criciúma) have been constructing transnational connections, fostering a unique social field that involves those who leave and those who stay. A complex network of relations exists to assist migrants upon departure and arrival, as well as in managing their investment in their hometowns.

\section{Absentees, Returning, and Transmigrants}

Between 1880 and 1985, one might say that Criciúma received many immigrants in search of work and residence. Since the Italian colonization initiated in 1880 until the vigorous growth of the coal mining industry until the first half of the 1980s, the city welcomed people from various regions of Santa Catarina, as well as from neighboring states. However, after the cut of subsidies provided for coal mining in 1989, the city was strongly impacted in job offers. With its weakened economy, the migration process that largely built the city inverted. Since then, Criciúma faces an exodus into the United States and Europe that is close to many other migratory processes studied by authors such as HALL (2003) and BHABHA (1998), and particularly by MARTES (2003; 1999), SALES (1999), BOM MEIHY (2004), SANTOS (2007), ASSIS (2004), CAMPOS (2003), and SIQUEIRA (2006). We have over a decade in this migration process.

The growing flow of people and goods in the last decades is one of the most intriguing and complex phenomena produced by the so-called Western modernity. Crossing the border from Mexico to the United States (evidently in illegal situations) is linked to a well-articulated network of tourist agencies (usually fronts), forged sociabilities, coyotes, and others. The number of people that obtain tourist visas (which can also be forged) to enter the United States and find work immediately upon arrival is no less significant. They almost always occupy functions foreign to them in Brazil, such as cleaners, construction workers, cooks, servers, maids, valets, and others. 
painters. Cleaning is an occupation not usually performed by men in Brazil but is performed by $9.6 \%$ of migrants, who are usually janitor servants and work under a woman, commonly wives or sisters. Migrant women concentrate their work on domestic service (39.2\%). From the total of women surveyed, $23.8 \%$ work as housekeepers ${ }^{14}, 10.4 \%$ as cleaners, and $5 \%$ as nannies. In addition to domestic services, women work in restaurants as waitresses (7.4\%), kitchen staff (6.4\%), clerks (4.5\%), bussers $(3.5 \%)$, cooks (2.0\%), and bakers (1.5\%). The other $15.1 \%$ work in other services. It's the income from remittances in secondary market dollars that migrants have been using to move Criciúma's economy. Either way, using Mexico or tourist visas, these Brazilians began to make a living with the dollars they received for illegal work done in the United States. It's then clear how migratory studies relate to the contemporary reality of Criciúma.

Based on what was investigated thus far, it's possible to infer that approximately half of the returnees ultimately return to the United States. When they cannot do so, they migrate to a European country (England, Portugal, Spain, Italy, and Germany are the most sought after). Frustrations of returning migrants from Criciúma are similar to those returning to Governador Valadares, as shown by Siqueira (2006). The impact of returning results in a problem that only begins to grow: what is to be done to a city in case everyone comes back to it? Today, more than $20 \%$ of its financial capacity revolves around money applied in Criciúma by the so-called foreigners. The growth of the construction and real estate sectors represents a lot of the investments made by returnees in the city. On the other hand, one aspect that deserves further investigation is that several migrants return with an illness. Spine issues, depression, skin problems, and other problems associated with precarious work conditions and long hours working in the United States.

José Eduardo Mondardo, the owner of real estate company Duda Imóveis, affirmed on April 13, 2008, that the work of foreigners is important for the city. He also

\footnotetext{
14 Therefore, similarly to other Brazilian and Latin-American immigrants (Hondagneu-Sotelo, 1994, Menjívar 2000, Sassen 1995), women are move towards domestic service.
} 
said that returnees had invested their savings in Criciúma, in small businesses or real estate. That is the case of those who undergo smoother adaptation, which is not many. In most cases, returnees arrive with altered living standards, much higher than the life they will have back home. So to meet or sustain a living standard that was previously reached in the United States, a considerable amount of returnees goes back to the United States. They almost always go undocumented or use their transnational links to commute between Criciúma and Boston region.

\section{Final remarks}

Migrants from Criciúma are part of an international migration wave that occurred throughout the 1990s. Similarly to the people in Governador Valadares, they went to America with a common migratory project: to buy a home and a car, as well as to start a business. This reveals an interesting aspect of the social networks acting upon migration. A part of the new migrants from Criciúma descended from Italian immigrants so that aid in getting Italian citizenship opens the European job market for them. However, instead of making the reverse path of their ancestors and migrate to Italy, they follow the path opened by other Brazilians of different regional origins and leave to the Boston area. Thus, one century later, people from Criciúma repeat the trajectory of their nonnos and nonnas, continuing their project of "making it in (the United States of) America."

This migratory experience places people in the process of cultural translation, of living between two places and two temporalities: here and there. It rearranges familial and affectionate arrangements, religious life, and ethnic or national identity. To them, this evidences that contemporary migration means experiencing a singular social field: a field of transnational relations.

As Campos (2008) ponders on what Homi Bhabha calls the "sudden disjunction of the present" that enables the global reach of culture, it is put as a survival strategy, both transnational and translational. Also according to Bhabha: "It is transnational because contemporary post-colonial discourses are rooted in specific histories of cultural displacement [...] and translational because these spatial stories of displacements bring 
The returning project would be, in a sense, the conclusion or materialization of the migration project - the end of a provisional stage in migration. Migrants want to return when they reach their objectives, which are usually to buy a home and a car, as well as to acquire the resources to set up a business. However, as accounts demonstrate, returning is more difficult than departing. Not only because of the critical context in which returns have been intensified and forced, but also because they fail to readapt back home. They feel strange, uncomfortable, out of place. "There it's good to work; here it's good to live [...], but when I get here, I want to go back there. I can't adapt."

Returnees no longer recognize their hometown, everyone and every place are strange to them. The experience of living abroad makes them feel foreigners at home, which is in itself a contradiction. Many find the city dirty and slow and complain about people disrespecting laws. They miss the North-American modernity and increased gender equality for women, especially those who are surprised to return to their "previous" gender position. So they feel displaced and have to rebuild their social relations and their homes. Many fail and re-migrate. Others go into depression, and those with green cards or American citizenships start structuring life between two places building transnational practices such as the Carminatis who live both here and there. Such would be the multi-faceted identity of the migrant of the new age.

\section{References}

ASSIS, Gláucia de Oliveira. De Criciúma para o mundo: rearranjos familiares e de gênero nas vivências dos novos migrantes brasileiros. Campinas, 2004, Tese (Doutorado em Ciências Sociais), Universidade Estadual de Campinas.

. A fronteira México-Estados Unidos: entre o sonho e o pesadelo as experiências de e/imigrantes em viagens não autorizadas no mundo global. Cadernos Pagu. ago-dez 2008.

. La Conexion Criciuma_EUA: un analisis de la configuracion de lazos transnacionales construidos por los e/inmigrantes del siglo XXI. Nuevos Retos del trasnacionalismo en el estudio de las migraciones, 2008. p. 1-20. 
. Estar aqui... estar lá... uma cartografia da vida entre dois lugares.

Florianópolis, 1995. Dissertação (Mestrado em Antropologia Social), Universidade Federal de Santa Catarina.

BHABHA, Homi K. O local da cultura. Belo Horizonte: Ed. UFMG, 1998.

CAMPOS, Emerson. Territórios deslizantes: miscelâneas e exibições na cidade contemporânea Criciúma (1980-2002). Florianópolis, 2003, Tese (Doutorado em História), Universidade Federal de Santa Catariana.

. Flujos contemporáneos: territorios y traducción cultural entre emigrantes brasileños no documentados en la región fronteriza México-Estados Unidos (1995-2007). Nuevos Retos del trasnacionalismo en el estudio de las migraciones. 2008. p. 1-20.

CAMPOS, Emerson Cesar de. Estrangeiros em casa: (re)sentimentos, impressões e identificações produzidas pelos emigrantes brasileiros clandestinos nos Estados Unidos 1995-2005. Relatório Final de pesquisa. FAED/UDESC, 2008.

CANCLINI, Nestor Garcia. A Globalização Imaginada. São Paulo: Iluminuras, 2003.

CPMI. Relatório Final da Comissão Parlamentar Mista de Inquérito da Emigração. Site: www.senado.gov.br/web/comissoes/CPI/Emigracao/relFinalCPMIEmigracao.pdf Acessado em: 4/18/2007.

FUSCO, Wilson. Redes sociais na migração internacional: o caso de Governador Valadares. Campinas, Núcleo de Estudos de População / UNICAMP, 2001. 85p.

GUIBERNAU, Montserrat; REX, John (orgs.) The Ethnicity reader: nationalism, multiculturalism, and migration. Maldon (USA): Polity, 2005.

HALL, Stuart. Da Diáspora: Identidades e mediações culturais. Belo Horizonte: UFMG; Brasília: representação da UNESCO no Brasil, 2003.

HIRSCHMAN, Charles; KASINITZ, Philip; WIND, Josh de. The handbook of international migration: the American experience. New York: Russell Sage Foundation, 1999.

HONDAGNEU-SOTELO, Pierrete. Gendered Transitions: Mexican experiences of immigration. Berkeley and Los Angeles, London. University of California Press, 1994.

IBGE. Estimativa populacional para 2005. Site: www.ibge.gov.br. Acessado em $18 / 04 / 2007$.

MARTES, Ana Cristina Braga. Brasileiros nos Estados Unidos: um estudo sobre imigrantes em Massachusetts. São Paulo: Paz e Terra, 1999.

MASSEY, Douglas, et al. 1987. The social organization of migration. In: Return to Aztlan: the social process of international migration from Western. Mexico Berkeley: University of California Press, p. 139-171. 
MENJIVAR, Cecília. Fragmented Ties: Salvadoran immigrant networks in America. Berkeley, Los Angeles, London. University of California Press, 2000.

PORTES, Alejandro. The economic sociology of immigration: a conceptual overview. In: Portes, Alejandro. The economic sociology of immigration. New York: Russel Sage Foundation, 1995, p. 1-41.

SALES, Teresa; FUSCO, Wilson; ASSIS, Gláucia e SASAKI, Elisa. As redes sociais nas migrações internacionais: os migrantes brasileiros para os Estados Unidos e o Japão. Relatório de Pesquisa FAPESP. São Paulo, 2002.

SALES, Teresa. Brasileiros longe de casa. São Paulo, Editora Cortez, 1999.

SANTOS, Maurício Aurélio dos. Crescimento e Crise na Região Sul de Santa Catarina. Florianópolis: UDESC, 1997.

SAVOLDI, Adiles. O caminho inverso: a trajetória dos descendentes de imigrantes italianos em busca da dupla cidadania. Florianópolis, 1998. Dissertação (Mestrado em Antropologia Social), Universidade Federal de Santa Catarina.

SIQUEIRA, Sueli. Migrantes e empreendedorismo na Microrregião de Governador Valadares: sonhos e frustrações no retorno. Belo Horizonte, 2006. Tese (Doutorado em Ciências Humanas: Sociologia e Política), Universidade Federal de Minas Gerais.

TEIXEIRA, José P. Os donos da cidade. Florianópolis: Editora Insular. 1996. VOLPATO, Terezinha Gasho. Os trabalhadores do carvão: a vida e as lutas dos mineiros de Criciúma. São Paulo, 1989. Tese (Doutorado em Ciências Sociais), Universidade de São Paulo.

ZAMBERLAM, Jurandir; CORSO, Giovanni (Orgs.). A emigração da Grande Criciúma na ótica de familiares - desafios para a igreja de origem e de destino. Porto Alegre: Solidus, 2007. 